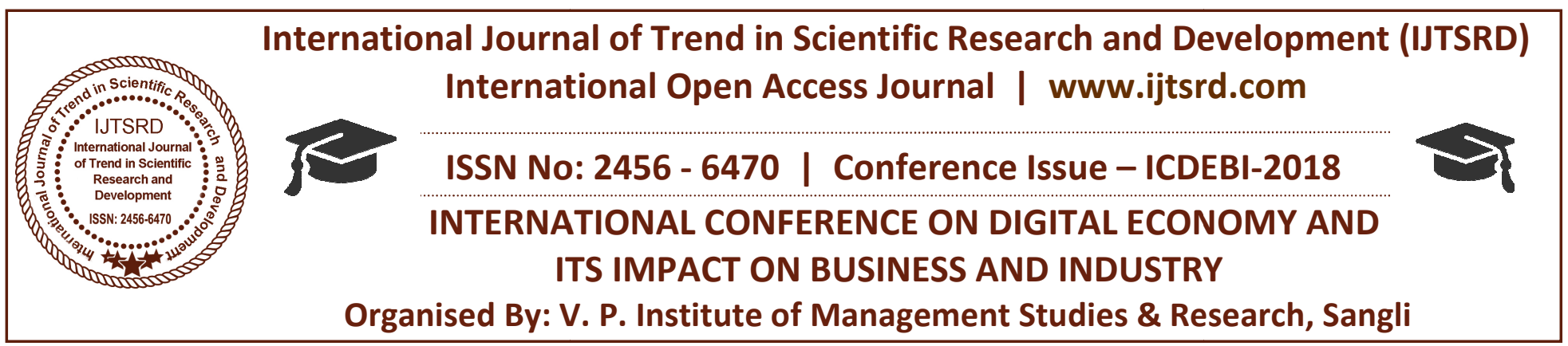

\title{
Effect of Digital India on Indian Society
}

\author{
Dr. Paul D Madhale \\ Head and Associate Professor, Management Faculty, \\ Sanjay Bhokare Group of Institutes, Miraj, Maharashtra, India
}

\begin{abstract}
Digital India is the result of numerous advancements and innovative headways. These change the lives of individuals from numerous points of view and will engage the general public in a superior way. The 'Digital India' program, an activity of respectable Prime Minister Mr. Narendra Modi, will emerge new movements in each part and creates inventive attempts forge next. The thought process behind the idea is to construct participative, straightforward and responsive framework. Digital India is a program to convert India in to a digitally empowered society, and knowledge economy. It is an ambitious program of Government of India projected Rs. 1,13000crores. This project is delivering good governance to people and coordinated with both State and Central Government. Henceforth, an endeavor has been made in this paper to comprehend Digital India as a crusade where advancements and network will meet up to have an effect on all parts of administration and enhance the personal satisfaction of nationals.
\end{abstract}

KEYWORDS: Digital India, Innovative, Society, Endeavour, Administration, Economy.

\section{INTRODUCTION}

Prime Minister Narendra Modi launched digitalization system in the country on 1st July, 2015. The plan for making India digital is to connect rural Areas with high speed internet networks. Digital India is a program to prepare India for a Knowledge future. Digital India is an initiative made by the PM Narendra Modi to transform India into digital empowered society and knowledge economy. This program is an ambitious program of Government of India with a project amount of rupees 1,13000crores. This program is for preparing India knowledge based. The words of PM Modi for Digital India are "The more technology we infuse in Governance the better it is for India". "Digital India is more for poor underprivileged. It Aims to bridge the gap between digital haves and have not's by using the technology for the citizens" words of Shri Ravi Shankar Prashad (the Hon'able Minister of Communication and IT Government of India).

The Digital India programme is a flagship programme of the Government of India with a vision to transform India into a digitally empowered society and knowledge economy. E-governance initiatives in India took a broader dimension in the mid-1990s for wider sect oral applications with emphasis on citizencentric services. The major ICT initiatives of the Government included, inter alia, some major projects such as railway computerization, land record computerization, etc. which focused mainly on the development of information systems. Later on, many states started ambitious individual e-governance projects aimed at providing electronic services to citizens.

Though these e-governance projects were citizencentric, they could make less than the desired impact due to their limited features. The isolated and less interactive systems revealed major gaps that were thwarting the successful adoption of e-governance along the entire spectrum of governance. They clearly pointed towards the need for a more comprehensive planning and implementation for the infrastructure required to be put in place, interoperability issues to be addressed, etc. to establish a more connected government.

There are three Vision Areas and Nine Pillars for the implementation of digital program in India. Digital 
India is a complex program that reduces the manual working of multiple departments. Digital India program is a use of computer technology and mobile applications for taking up of Government services quickly. Digital India today Digitalization system in India will not only makes changes in government processes, policies, increases but also brings about huge democracy in the economy of a country. This becomes a major innovative program for the economic development of our country. Vision of digital system is the development of a country through electronic technology and for creating more job opportunities

\section{The components of Digital India are:}

$>$ Creating Digital infrastructure.

$>$ Providing of services digitally.

$>$ Digital literacy.

\section{Infrastructure as a utility to every citizen}

The initiative is aimed at providing connectivity through fixed-line broadband, mobile connectivity or Wi-Fi hotspots. Every citizen would be provided with a unique identity with lifelong validity that can be tied up with mobile number and bank account to enable digital banking. Access to Common Service Centre (CSC) would be improved and shareable cloud space on public cloud servers would be provided.

\section{Governance and services on demand}

The initiative plans to create seamless integration across multiple government departments and jurisdictions, and make services available on online and mobile platforms. Financial transactions would be made cashless and electronic, and entitlements would be available on the cloud. The ease of doing business in India would be improved.

\section{Digital empowerment of citizens}

The initiative would provide universal digital literacy to empower citizens to use digital platform/devices. Universal access to digital resources would be provided, wherein all documents would be available in digital form on the cloud. Government services would be provided in local languages and a platform would be made available to citizens for participative governance.

\section{Vision of Digital India:}

$>$ High speed digital highways unit the nation.

$>1.2$ connected Indians drive innovation.

$>$ Access to information no barriers.
Technology ensures the citizen- government interface is incorruptible.

$>$ Government services are easily and insufficiently available to every citizen's mobile devices. Government proactively engages with the people through social media.

$>$ Quality education reaches the most inaccessible corners driven by digital learning.

$>$ Quality healthcare percolates right up to the remotest regions powered by e-healthcare.

$>$ Farmers are empowered by real-time information to be connected by the global markets.

$>$ Mobile enable emergency services ensure personal security.

Mobile and e-banking ensures financial inclusion.

$>$ E-commerce drives entrepreneurship. Here are some of the projects and products that have been launched, or are ready for deployment, as part of the Digital India initiative:

$>$ Digital locker system to minimize usage of physical documents and enable their e sharing via registered repositories.

MyGov.in as an online platform to engage citizens in governance through a "Discuss, Do and Disseminate "approach.

Swachh Bharat Mission Mobile app to achieve the goals set by this mission.

E-Sign framework to allow citizens to digitally sign documents online using Aadhaar.

> E-Hospital system for important healthcare services such as online registration, fee payment, fixing doctors' appointments, online diagnostics and checking blood availability online.

National Scholarship Portal for beneficiaries from submission of application to verification, sanction and disbursal.

Digitize India Platform for large-scale digitization of records in the country to facilitate efficient delivery of services to the citizens.

$>$ Bharat Net programme as a high-speed digital highway to connect all 250,000 gram panchayats of country -- the world's largest rural broadband project using optical fibre.

$>$ BSNL's Next Generation Network to replace 30year old telephone exchanges to manage all types of services like voice, data, multimedia and other types of communication services.

$>$ BSNL's large scale deployment of Wi-Fi hotspots throughout the country. 'Broadband Highways' as one of the pillars of Digital India to address the connectivity issue while enabling and providing 
technologies to facilitate delivery of services to citizens.

$>$ Outsourcing Policy to create such centres in different north-eastern states and in smaller towns across the country.

$>$ Electronics Development Fund to promote innovation, research and product development to create a resource pool within the country as also a self-sustaining eco-system of venture funds.

$>$ National Centre for Flexible Electronics to promote research and innovation in the emerging area of flexible electronics.

$>$ Centre of Excellence on Internet on Things (IoT) as a joint initiative of the government agencies and private institutions such as Nasscom.

$>$ To make Post Offices multi-service centres.

$>$ To connect all schools with broadband and free Wi-Fi.

\section{OBJECTIVES:}

1. To study the concept of Digital India \& Its Services.

2. To know the Vision of Digital India with innovative ideas and practical solution.

3. To Know Citizens perception about Digital Services in Rural Areas.

\section{LITERATURE REVIEW:}

'Digital India' initiative has been an area of interest of numerous researches from various disciplines because of its great significance and influence on the economy as a whole and particularly the technological sector.

SundarPichai, SatyaNadella, Elon Musk researched about Digital India and its preparedness to create jobs opportunities in the information sector. He concluded that creating new jobs should be continued with shifting more workers into high productivity jobs in order to provide long term push to the technological sector in India.

Microsoft CEO, Satya Nadella intends to become India's partner in Digital India program. He said that his company will set up low cost broadband technology services to 5lakhs villages across the country.

Prof. Singh began with the basic overview of what Digital India entails and led a discussion of conceptual structure of the program and examined the impact of "Digital India" initiative on the technological sector of India. He concluded that this initiative has to be supplemented with amendments in labor laws of India to make it a successful campaign.

Arvind Gupta intends to say that Digital India movement will play an important role in effective delivery of services, monitoring performance, managing projects and improving governance. An Integrated Office of Innovation \& Technology to achieve the same, for problem solving, sharing applications and knowledge management will be the key to rapid results, given that most departments work on their own silos. Tracking and managing the projects assumes significance because India has been busy spending money in buying technology that we have not used effectively or in some cases not even reached implementation stage. Sharing learning's and best practices across departments needs to be driven by this Office of Technology.

Gupta and Arora (2015) studied the impact of digital India project on India's rural sector. The study found that many schemes have been launched in digital India to boost agriculture sector and entrepreneurship development in rural areas. Digital India programme has also set the stage for empowerment of rural Indian women.

Rani (2016) concluded that the digital India project provides a huge opportunity to use the latest technology to redefine India the paradigms of service industry. It also pointed out that many projects may require some transformational process, reengineering, refinements to achieve the desired service level objectives.

Midha (2016) concluded that digital India is a great plan to develop India for knowledge future butits improper implementation due to inaccessibility and inflexibility to requisite can lead to its failure. Though digital India programme is facing number of challenges yet if properly implemented it can make the best future of every citizen. So we Indians should work together to shape the knowledge economy.

\section{RESEARCH METHODOLOGY:}

Being a Descriptive research it is based on Primary as well as secondary data.

Primary Data: In this present study, I have collected primary data through Google forms (Questionnaire) from the respondents. 
Secondary Data: The major sources of secondary data for present study are - E-Governance Reports, EReadiness Reports, Govt. reports and circulars, Newspapers, Magazines and Periodicals, Journals, Conference proceedings, Internet, Websites, eliterature and Books.

Therefore, a citizen's survey was undertaken with help of a Goggle forms questionnaire that Researcher send it link to the around 150 respondents mail id to study the impact of Digital India projects on Indian Society at Sangli district. Among this 150 respondent researcher has got the response of 118respondents within a time given frame.

\section{Limitations of the Study:}

The present study is confined to a minimal sample size and may not reflect the opinion or response of the whole population. There were only 118respondents taken for the survey. The results of my study are entirely confined to the responses of the Sangli district and may deviate in terms of actual population as a whole recommendation given after the study are entirely dependent on the survey and the secondary \& primary analysis done in the report.

\section{NINE PILLARS OF DIGITAL INDIA:}

1. Broadband Highways: The Government of India launched Digital India program with the vision of broadband networks all over the country in which government allocated 5 billion to connect high speed broadband highways for connecting all the villages, government departments, institutes and universities. For fulfilling this pillar, the National optical fiber network (NOFN) is launched. Investment in this project is funded by Universal services obligation fund, it has set the process for connecting broadband networks to the country's 2, 50, 000 gram panchayats by year 2016.

\section{Universal Access to Phones: In this Pillar,} Government of India focuses on network connectivity and filling the gap in connecting the different areas of the country to mobile access or network with the help of internet coverage. In the past years, network technology like $2 \mathrm{G}$ was running in the country which was at one time becomes the most useful network connect but then there becomes a need for the further high speed connectivity to reach the maximum of areas within the country as in some of the areas, there was no coverage for $2 \mathrm{G}$ networks. Government felt the need for the start up of new and modified network and for this they have started with $3 \mathrm{G}$ and $4 \mathrm{G}$ which we are using today for better and efficient mobile connectivity. But still, there is a need arise for the further more improved internet connectivity and for this government is focusing on $5 \mathrm{G}$ network connectivity in future period.

3. Public Internet Access Program: The two components of this pillar are common service centres (CSC) and Post office as Multi service centres. This Pillar focuses on connecting the National Rural internet mission. It consists of those technologies that support effective cost, security, services, connectivity that delivers remote access to any information or service available across the domain. This change in technology will open new doors of e-services to every citizen i.e. E-governance. E-Governance is an easy services delivery program government started for connecting with the public. Common Service centres are the centres that cover the local area for nearby places. It provides multi end point for service delivery. Its coverage is $2,50,000$ villages.

\section{E-Governance -Reforming Government} through Technology: E- Governance is a ReEngineering process of government business using IT to improve its processes and policies. This pillar is formed by government for transforming government to e-government and its governance to e-governance. E-Governance is the situation where the interaction with the government can be done through one counter, 24 hours a day, 7 days a week without waiting in queues at Government offices. Each citizen can make a contact with government through a website where all forms, laws, news and other information will be available. This model of EGovernance could be put to three categories: G2G, $\mathrm{G} 2 \mathrm{~B}$ andG2C.

5. E-Kranti - electronic delivery of services: eKranti means electronic delivery of services to public. This e-Kranti focuses on providing information and knowledge to people regarding health, farming, rights, and financial services electronically with easy access. Government of India has allocates 5 billion for eKranti projects in the country. It includes the following sub projects: 
International Journal of Trend in Scientific Research and Development (IJTSRD) ISSN: 2456-6470

\begin{tabular}{|c|c|}
\hline Projects & Service Offered \\
\hline e-Education & $\begin{array}{c}\text { Literacy programme and Wi-Fi connectivity in schools } \\
\text { Online graduate and Master degree courses }\end{array}$ \\
\hline e-Health & $\begin{array}{c}\text { Online medical consultation } \\
\text { Online medicine supply and records }\end{array}$ \\
\hline e-Farming & $\begin{array}{c}\text { Online availability of real time price information } \\
\text { Online ordering of inputs and loan payments }\end{array}$ \\
\hline
\end{tabular}

6. Information for All: The next pillar for implementation of Digital India project in India is availability of information for all. Two way communication system between government and citizens. Availability platform for open data makes easier for the citizens to take the benefit of all services under a single system of information. Government of India has launched a web based online site for public access for quicker and easier access and interaction. Government started data.gov.in website for interacting with public.MyGov.in is a website implemented by government of India as a platform for citizens to engage in governance.

7. Electronic Manufacturing- Target Net Zero Imports by 2020: This Pillar focuses on promoting manufacturing of electronics in the country and not to be imported from outside the country. This will promote and develops industrialization in India. This fabulous aim can be achieved only by the coordination between the following actions: By making suitable changes in taxation system by the government for motivating the industrial sector for manufacturing electronics, development of Skills and talent, by enhancing and providing fund to $\mathrm{PhD}$ students in universities across the country for research in manufacturing of electronic.

8. IT for Jobs: This pillar focuses on providing training to youth for developing their skills required for jobs opportunities in IT sector. There are three components for completing this aim. First component is to provide training to youngsters to build them eligible for getting jobs in IT sector. The target for achievement of this aim is to train 1 crore students from small towns, villages for IT jobs within a period of 5 years.

The second component is to establish BPO's in every north eastern states to enable ICT growth in these sectors.

The third component of this pillar is to train 3 lakh service delivery agents to run viable business delivering IT services. IT parks are established by government of India in different states for the development of skills and talent of youth in the country like IT Park in Chandigarh, Bharat Electronics limited in Panchkula(Haryana).

9. Early Harvest Programs: This pillar focuses on the generation of short timeline projects which replaces manual services by transformation of manual services to e-services. These includes $\mathrm{Wi}-\mathrm{Fi}$ in all schools, colleges and Universities, IT platform for messages, Public Wi-Fi hotspot, Biometric attendance, Government greetings to e-greetings, SMS based weather information

\section{Impact:}

The estimated impact of digital India by 2019 would be cross cutting, ranging broadband connectivity in all panchayats, Wi-Fi in school and universities and public Wi-Fi hotspots. The programme will generate a huge number of IT, telecom and electronics jobs, both directly and indirectly. Success of this programme will make India digitally empowered and the leader in usage of IT in delivery of services related to various domains such as health, education, agriculture banking, etc.

\section{Effects of Digital India Project by 2019:}

$>\mathrm{Wi}-\mathrm{Fi}$ in 2.5 lakh educational institutions, all universities; Community Wi-Fi locations for people.

Job creation: Immediate $1.7 \mathrm{Cr}$. and Oblique at least $8.5 \mathrm{Cr}$.

$>$ India to be innovator in IT use in solutions health, knowledge, financial.

$>$ High speed internet in 2.5 lakh villages, universal phone connection.

$>$ 400,000 Community Internet Access Point.

$>$ Digital Inclusion: $1.7 \mathrm{Cr}$ qualified for IT, Telecommunications and Electronic devices Jobs.

Net Zero Imports by 2020.

$>$ E-Governance \& e-Services: Across government.

$>$ Digitally motivated people - public reasoning, internet access. 


\section{FINDINGS \& CONCLUSION:}

1. Most of the people are of $26-35$ age groups.

2. Most of the respondents are doing job.

3. Most of the people are aware of Digital India Project.

4. Digital India Project will go to uplift the standard of living.

5. People want to live in a city where every work is digitalized.

6. Literacy to every other rural people and providing digital education is very important thing to convert India Digitally.

7. Rural people can able to adopt the digital changes only if they will be given proper guidance of digital literacy \& knowledge.

8. After digitalization, educational institutes will become more convenient as compare to their current services.

9. Digital literacy is the idea of Digital India according to most of the people.

10. According to most of the people, Digital India Project has been rated as 'Excellent' as well as 'Good'. Most of the people are aware of Digital India. From the survey, we have concluded that Digital India Project will definitely uplift the standard of living. People want to live in a digitalized city as it will provide better lifestyle through digital services. Rural area people will also be able to adopt the digital changes only if government of India will provide the proper training and digital literacy. Without a proper digital training, it will be difficult for the Indians to get comfortable with digital changes in the country. Digital India will be providing lots of job opportunities and will help in reducing unemployment from the country. Especially IT people will get a good opportunity to showcase their technical skills. The job will be mostly white collar job which will raise the standard of living in the country. Service sector will also undergo vast change as people will able to get all the work done digitally. The time taken to complete each task will reduce to minimum. It is possible that after digitalization, there will be Net-Zero imports in the economy by 2020. GDP of country will also be affected by this project. This project will definitely bring prosperity \& up gradation to country but certain drawbacks are there as it is fully related to technology. Security may become the matter of concern. Other than this, the error in the system may be lead to a serious problem. People have lots of expectations towards this project. Government of India has to stand upon the expectations.

\section{RECOMMENDATION:}

1. Indian government need to start providing digital literacy to every other citizen.

2. To create impact of Digital India to be realized, we have to use technology to solve problems faced by Indians and for that we need a very strong culture of grounds-up frugal innovation in IT.

3. Our recommendation to the government would be to set up PPP forums in each of these segments to invite industry to participate in areas where they have the domain expertise and interest.

4. The government has set the stage with a strong vision and an equally strong show of will to make it happen. What we need now is for them to focus on setting the right policy frameworks and processes that make it easy for industry to do business in India and encourage us to participate in India's journey towards becoming a digital India.

5. What are needed now are an unprecedented focus and the will to make it happen across both government and industry.

6. The one area where this kind of a model is needed with a high level of urgency is in developing the culture of innovation in India.

7. The government must encourage open global standards that will enable India to benefit from the best technology worldwide.

8. The government should also focus on sustainable development and basic facilities of rural area before providing them digital services. These two have to go hand-in-hand.

9. The numbers are mind boggling, but they can be achieved, especially as rapid pace of innovation is increasingly making technology more favorable for mass scale adoption, which is a must for the successful realization of Digital India.

10. It is recommended that every citizen must realize that such an important and enormous vision cannot be the government's job alone. We have to be an equal partner in this journey.

\section{REFERENCES:}

1. Gupta, N., \& Arora, K. (2015). Digital India: A Roadmap for the Development of Rural India. International Journal of Business Management, 2(2), 1333-1342. 
International Journal of Trend in Scientific Research and Development (IJTSRD) ISSN: 2456-6470 | IF: 4.101

2. Gupta Neeru and Arora Kirandeep (2015). Digital India: A Roadmap for the development of Rural India.

3. International Journal of Business Management, $\operatorname{vol}(2) 2$, pp1333-1342. Retrieved from www. ijbm.co.in

4. Arvind, P. P., Vitthalrao, M. P., \&Mukund, J. M. (2015). Digi Locker (Digital Locker): Ambitious aspect of Digital India Programme. GEInternational Journal of Management Research, 3(6), 299-308.

5. Goswami, H. (2016).Opportunities and Challenges of Digital India Programme
International Education and Research Journal, 2(11), 78-79.

6. Midha Rahul (2016). Digital India: Barriers and Remedies. International Conference on Recent Innovations in Sciences, Management, Education and Technology. Retrieved from http:// data.

7. Conference world .in/ICISMET/P256-261. Pdf.

8. The Digital India book'-(by Deity)

9. The Times of India'

10. Economics Times'

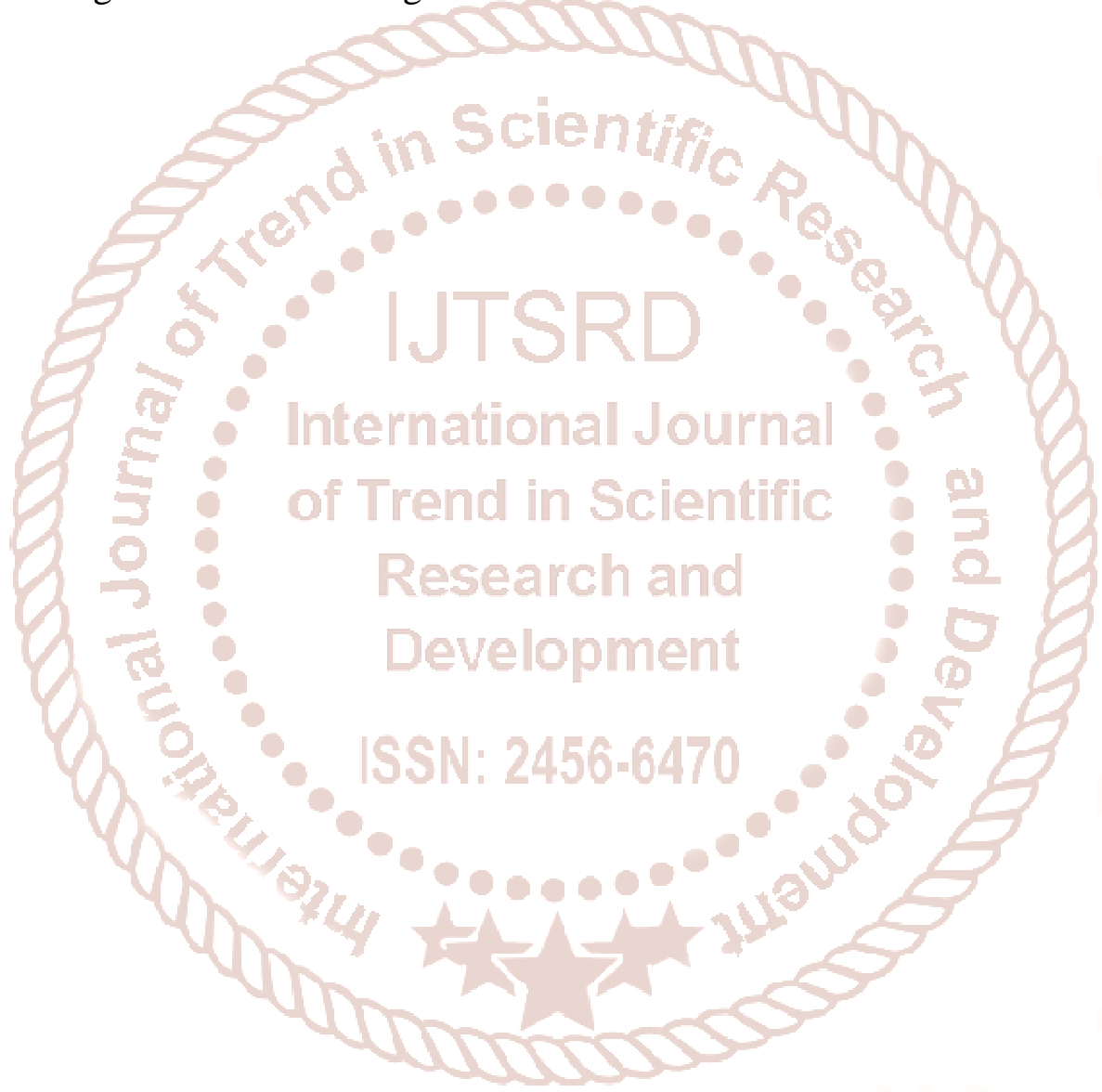

